\title{
Japán és német kultúra beillesztése a Magyar vállalat működésébe
}

\section{The implementation of the Japanese and the German culture into the operation Hungarian firm}

\author{
Z. NAGY TAMÁS \\ KnottTechnik-flex Kft., AutóflexKnott Kft,, monika.nagyne10@gmail.com
}

\begin{abstract}
Absztrakt. Magyarországon müködö- részben német tulajdonban lévő vállalat- múködésébe, hogyan lehet beilleszteni a japán kultúrát. A bemutatásra kerülő cikkemben a különböző szervezeti kultúra modelleket tanulmányoztam, és párhuzamba állítottam a mi vállaltunk szervezeti kultúrájával, hasonlóságokat és ellentéteket kerestem. Megvizsgáltam azokat a környezeti tényezőket, erőforrásokat, amelyek hatással vannak a gyártásra. A tanulmányozás során azt is figyelembe vettem, hogy a különböző nemzetiségek kultúrait, hogyan lehet összehangolni, és ezek összességében hogyan hat ki a termelésre. A robotok alkalmazásának bevezetését tanulmányoztam, és arra kerestem megoldást, hogyan lehetne a gyártást minél gazdaságossá tenni. Sajnos ugyanis a népesség folyamatos csökkenése, és a szakember hiány miatt robotokat kell alkalmazni ahhoz, hogy a vevőket időben, megfelelő mennyiségü és az elvárt minőségü áruval lehessen kiszolgálni. A japán, Toyota-módszer szerint csak akkor sikeres automatizálni egy technológiát, ha az legalább tízszer van letesztelve, erre azonban- a rendelkezésre álló idő hiánya miatt- nincs lehetőségünk. Mivel a gyártási paraméterek, a tapasztalatok még nem megfelelö módon alakultak ki, ezért a selejt termék aránya még magasabb, mint ahol elegendő idő áll a rendelkezésre, a technológia kialakítására.
\end{abstract}

Abstract. How can the Japanese culture be implemented into the operation of a firm - partly a German property working in Hungary. In my presented arcticle I have studied various organisational culture models, and compared them to the culture of our enterprise, seeking for similarities and contraries. I have studied the environmental factors and resources which have an effect on our production. During the investigation I have also considered how can we harmonize cultures of different nations and how it affects the production on the whole. I have also investigated the installation of robots, and searched for the solution how we can make our production much more economical. Due to the persistent decrease of population, and leck of professionals, the use of robots is neccessary to fulfill the customer requirements in time, with the sufficient quantity and required quality of goods. According to the Japanese Toyota-method,theautomatization of a technology can only be successful, if it is tested at least ten times, but -beacuse of the leck of time- we do not have the possibility of it. As the manufacturing parameters and observations have not developed the proper way, the scrap rate is higher than it is at firms, where is more available time for the building up of the technology. 


\section{Irodalmi áttekintés}

\subsection{A szervezeti kultúra a vállalatok életében}

A szervezetekben megjelenő kulturális elemek vizsgálatával két-három évtizede kezdtek el foglalkozni. A vállalat középpontjában az ember áll, amit már 1922-ben Heinrich Licklisch meg is fogalmazott. A szervezeti kultúra tehát nem új keletű fogalom. Ahhoz, hogy megértsük a szervezet kultúráját, meg kell ismerni a szervezet tagjait és a környezetüket.

A szervezeti kultúra megfogalmazására számos meghatározást találhatunk. Bakacsi szerint „A szervezeti kultúra nem más, mint a szervezet tagjai által elfogadott, közösen értelmezett előfeltevések, értékek, meggyőződések, hiedelmek rendszere. Ezeket a szervezet tagjai érvényesnek fogadják el, követik, s az új tagoknak is átadják."[1]

Tóth Antal könyvében pedig azt olvashatjuk, hogy, A szervezeti kultúra egy adott szervezetet alkotó közösség kultúrája."[2]

A vállalat, hogy elérje célkitűzéseit, megfeleljen az elvárt vállalati politikának, az egyént kell fejleszteni, motiválni. Ha az egyén gondolkodásmódja és a cselekedete megegyezik a szervezet elvárásaival, akkor meg tudja valósítani a vállalat a céljait. Ahhoz, hogy a szervezeti kultúrát egységesen ki tudják alakítani, az egyén, a munkatársak motiválása szükséges. Elsősorban stabil munkahelyet kell biztosítani, ahol a dolgozók érzik a hovatartozásukat. Szükséges a dolgozók teljesítményének elismerése, amennyiben a kitűzött feladatokat hatékonyan oldja meg, úgy jutalomban kell érte részesíteni, erre az egyik eszköz az anyagi motiváció.

A szervezet tagjai részére úgy kell a feladatokat megfogalmazni, hogy az számukra érthető legyen, és ezeket a vezetők kontrollálni is tudják. A jó munkahelyi légkör megteremtése is nagyon fontos, hogy a munkájuk tényleg eredményes legyen. Az eredményességre a motiváció pozitívan hat, ezáltal még jobban, nagyobb szakmai hozzáértéssel fogják a feladataikat elvégezni, egységes csapatként dolgoznak, és ez által válnak lojálissá, a vállalatra jellemző szervezeti kultúra iránt.

\subsection{Szervezeti kultúra modellek}

A szervezeti kultúra leírására különböző modelleket alkottak. Ilyen aMüri által alkotott Jéghegy modell, a Handy, a Quinn, vagy Hofstede modellje.

A Jéghegy modell a szervezeti kultúrát egy jéghegynek tekinti, melyből $10 \%$ a víz feletti rész, ezek a látható jegyek a környezettel vannak kapcsolatban. Idetartoznak a ceremóniák, történetek, nyelvezet, szimbólumok, ezek minden laikus számára észrevehetőek. Az igazi értékek a víz alatti részen vannak, ezt csak a dolgozók ismerik, akaratukkal képesek befolyásolni, és sokszor ezek az elemek, láthatatlanok is maradnak. Ilyen láthatatlan jegyek az értékek, a hiedelmek, az érzések és az attitűdök, amelyek a szervezeti kultúra 90\%-át teszik ki.[3]

Handy szerint a vállatoknál a szervezeti kultúrát főként az határozza meg, hogy milyen tevékenygégeket végeznek, és ez alapján négy csoportot alkotott: 
- Hatalomkultúra-Pókháló

- Szerepkultúra-Görög oszlopcsarnok

- Feladatkultúra-Háló

- Személyiségkultúra-Halmaz.

Quinn is négy kultúratípust ír le; a támogató, szabály orientált, célorientált, valamint az innováció orientáltat, a szervezet hatékonysága és az emberi értékrendje közötti kapcsolat alapján.[4]

Hofstede hatalmas adatbázist hozott létre, a kutatási eredményeiből. Vizsgálta a vezető és a beosztottak közötti kapcsolatot, amely a hatalmi távolsági indexet (HTI) adja. A bizonytalansági indexszel (BTI) azt írja le, milyen erős a szabályokhoz való ragaszkodás, a stressz okozta hatások, milyen mértékű a fluktuáció. Az individualizmus-kollektivizmus terén milyen a kapcsolat az egyén és a közösség között, és ez által milyen kapcsolat lesz jellemző az egész szervezetre. Fontosnak tartja a férfias és a nőies értékek meghatározását. A maskulin azaz férfias erők a rámenősek, míg a nők a gondoskodóak, ezek a szakmák, munkahelyek megválasztására meghatározók, ezért a nők inkább korházakba mennek el dolgozni, betegeket ápolni. Ennek a négy indexnek a segítségével állít fel négy szervezeti kultúra modellt. Az angolszászok, skandináv országokra jellemző a piac típusú szervezeti kultúra, ahol a dolgozók és vezetők között alacsony a hatalmi távolság és gyenge a bizonytalanságkerülése. A német nyelvű és kultúrájú országok, a magyarok az „olajozott gépezethez” tartoznak. A másik csoportban a családi típusú szervezeti kultúrák találhatóak a délkelet-ázsiai országok. A latin kultúrák és az iszlám országok a piramis csoportba tartoznak, ahol a szervezetre a vertikális tagozódás a jellemző.

Az 1. ábrán az látható, hogy Hofstede hogyan osztotta szét az országokat a négy különböző szervezeti kultúra típus között. A különböző nemeztek szervezeti kultúrájának megértésében a történelmi események ismerete sem elhanyagolható.

A német szervezeti kultúrára a stabilitás a biztonság a legfontosabb érték, a mérnököket hősöknek tekintik, a munkásoknak nincs inspiráló vezetőre szükségük. A munkásoknak a feladatokat ki kell jelölni, amelyet önállóan végeznek el, a technikai problémáknál a vezetőktől azt várják el, hogy szakértőként segítsék őket.

A japán kultúrában az egyéni érdekek a csoport, a közösség, a társadalmi érdekei mögé szorulnak. Nem csak a társadalomban, hanem a termelésben is csoportokat alkotnak, ezek a csoportok felelősséget várnak el a tagjaitól, de a csoport is felelősséget vállal a tagjaiért.

Hofstede szerint a magyar szervezeti kultúrára a kis hatalmi távolságok, a közepesnél erősebb individualizmus a jellemző, erős maszkulin értékekkel. A kis és középvállalatok óvakodnak a nagyobb vállalattal való kapcsolattól, kerülik a külföldi piacra történő betörést. Nem terveznek hosszú távra, sőt amint megjelenik az anyagi nehézség, inkább feladják a vállalkozást, pedig a magyar munkaerőt szorgalmasnak tartják, csak nem kellően kitartónak.[5] 


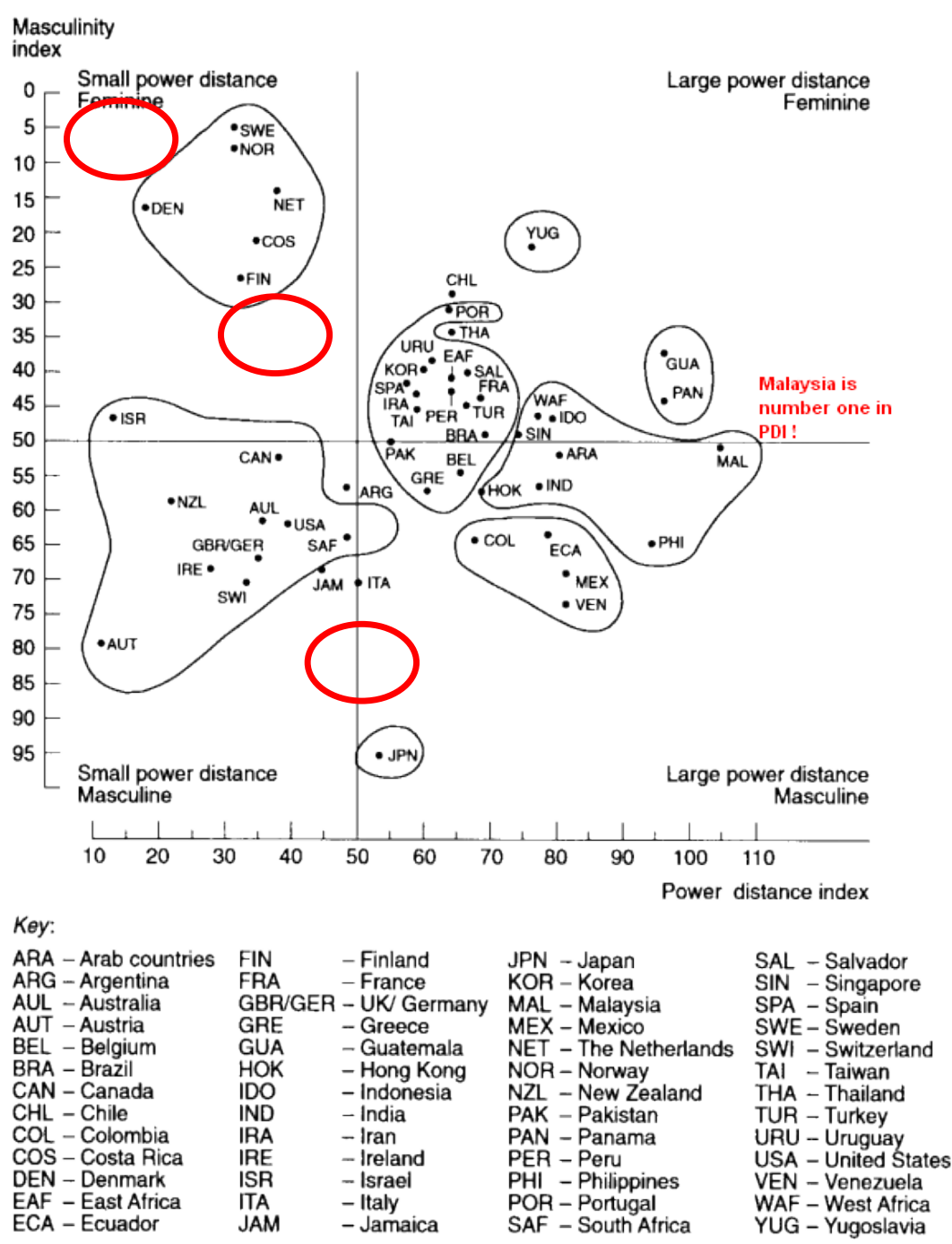

\section{1. ábra: Hofstede ábrája}

(Forrás: [10])

\section{Hol helyezkedik el vállalatunk Hofstede ábráján?}

Hofstedeáltalános kutúra-tipológiaiábrája alapján megállapítható, hogy a német, magyar és japán kultúra mennyire különböző vonásokat tartalmaz, ebből is látható, hogy három különböző szervezeti kultúra egyesítését tűzte ki a vállalat, hogy a múködésében a legjobb hatékonyságot érje el.

\subsection{A vállalat bemutatása}

Vállalatunk, az AutóflexKnott Kft, 1982-ben Kecskeméten megalapított vállalkozás, több termelőüzemmel szinte a teljes világpiacot látja el az utánfutó- technikai alkatrészeivel. Először az utánfutókat készre gyártották, de miután csatlakozott a német Knott céghez (1994-ben), csak a tengelygyártás maradt a kecskeméti telephelyen. 
A Knott anyavállalattal 50-50\%-os tulajdonosi viszonyban van, de teljes önállóságot élvez a technológiai fejlesztések terén, nincsenek előzetes egyeztetésekhez kötve a beruházások, és megszorításokat sem alkalmaz. Információkat az időszakos jelentésből nyernek, illetve évente egy alkalommal úgynevezett Finance Meetingen az egész cégcsoport pénzügyi eredményeit tárgyalják meg, valamint a további tervek is napirendre kerülnek.

A Knott nagy múltra visszatekintő vállalat, európai üzleti kultúrája miatt komoly háttérrel rendelkezik, ami nagy biztonságot jelentett és jelent. Nagy segítség volt a Knott nevével fémjelezve bejutni a nyugat-európai piacra, és a fokozott ellenőrzésük az általunk gyártott termékek minőségét szolgálta. Gyorsan, rugalmasan megfelel a piaci kihívásoknak, ami annak köszönhető, hogy mind a Knott csoport, mind az Autóflex csoport - a számos leányvállalatainak a segítségével - rendkívül hatékonyan fel tudja venni a versenyt a konkurenciával szemben.

A leányvállalataink között van öntöde, kovácsüzem, acélcső gyár, gumi-, és műanyag gyártó üzem, tüzihorganyzó üzem és még számos más üzem, melyek segítségével rugalmasan és költséghatékonyan fel tud lépni a termékgyártás területén. A cégcsoport igyekezett a főbb termék csoportok gyártását arra a leányvállalatra bízni, ahol a legszínvonalasabb, legmodernebb és legoptimálisabb gyártási kultúrát tudtak megteremteni.

\subsection{Külső tényezők hatása a termelésre}

Ahhoz, hogy reális képet kapjunk a vállalatunk szervezeti kultúrájáról a külső környezeti tényezőket is figyelembe kell venni. Ilyen fontos tényező az emberi erőforrás is.

A KSH adatai alapján, láthatjuk, hogy az utóbbi 5 évben is jelentős a lakosságszámának a csökkenése, melyet az 2. ábra szemléltet.

A népesség folyamatos csökkenése, szakember hiányt okoz a munkaerő piacon, közben a vevői igények- úgy a minőség, mint a mennyiség terén is- egyaránt nőnek. A szállítási határidők pedig egyre csökkennek, aminek betartása elengedhetetlen követelmény vállalatunk számára is.

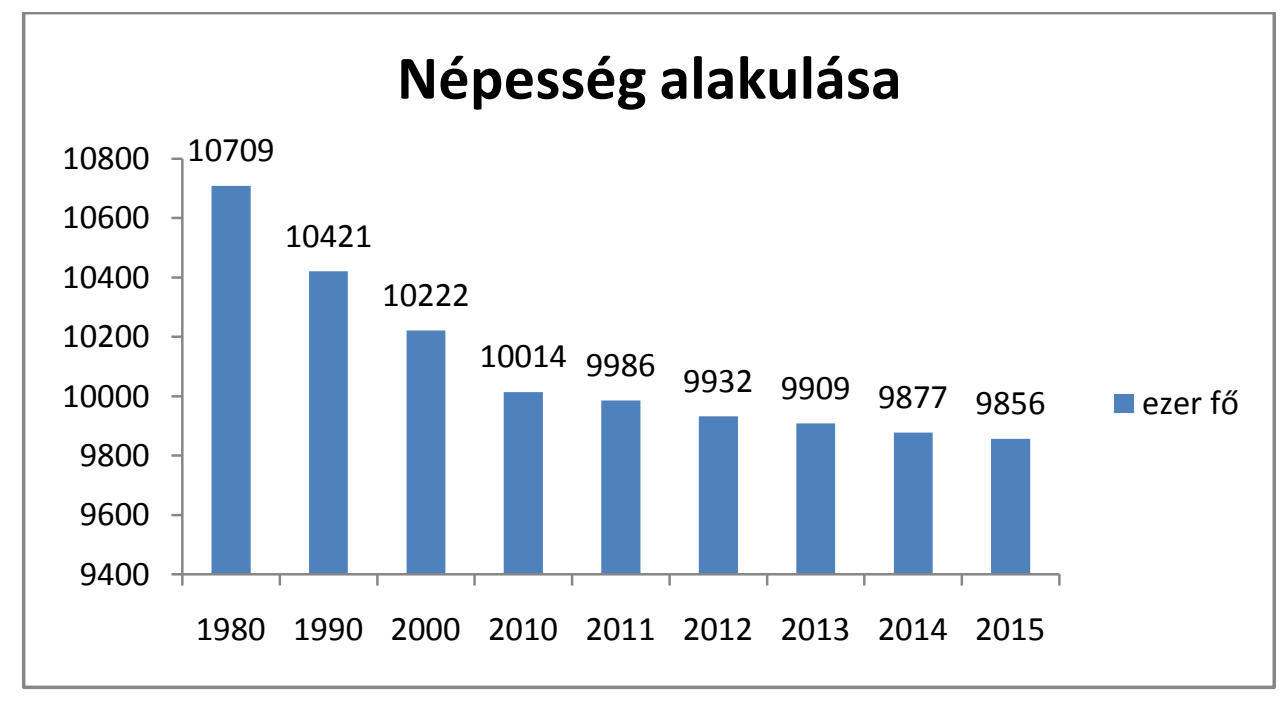

2. ábra: Népesség alakulása 


\section{(Forrás: saját szerkesztés a KSH adatok alapján)}

\subsection{Termelés kiegyenlítés}

A termelés kiegyenlítése azt jelenti, hogy a lehető legkisebb időegység alatt ugyanannyit gyártunk, amit az isbefolyásol, hogy a korábban fennálló különböző veszteségek a minimálisra csökkennek.

A Toyota termelési rendszere a veszteségeket három csoportba sorolja:

- a MURA a hullámzó terhelésekből fakadó felesleges folyamatokat-,

- a MURI a túlterhelésből fakadó veszteségfajtákat jelenti,

- a MUDA pedig az olyan alapvető veszteségeket jelenti, mint pl. a termékek-, anyagok felesleges mozgatása, a felesleges készletek, a különböző hibák, selejtek vagy éppen a várakozási idők stb. által okozott veszteségek.[6]

Vállalatunknál a vevői igények elég nagy ingadozást mutatnak, aminek megfelelő kiszolgálását még az is nehezíti, hogy a megrendeléstől számítva, viszonylag már rövid határidőn belül kell szállítanunk az árut a vevőnek. A maximális rendelésmennyiség időbeli és minőségi kiszolgálása magas dolgozói létszámmal történő termelést jelent. Ha azonban ezt a dolgozói létszámot folyamatosan fenntartjuk, akkor a megrendelési igény csökkenésével a megtermelt áru mennyisége a raktárkészletünket növelné. Ennek elkerülése érdekében bérmunkaerőt is szoktunk alkalmazni. A megnövekedett rendelési igényeket tehát a bérmunkaerő segítségével szolgáljuk ki, akiket rugalmasan lehet alkalmazni. Ezzel a magas raktárkészletek is elkerülhetők. Nagyon fontos, hogy a „kisegítő” dolgozók, ne a kulcs fontosságú feladatok ellátását végezzék, azt az Autóflex saját munkavállalóival oldja meg. Az 1. táblázatban azt mutatom be, hogy a „saját” dolgozóinkon kívül a bérelt munkaerő száma az utóbbi időben jelentősen megnövekedett.

\begin{tabular}{|l|l|l|}
\hline Évek & saját dolgozók (fó) & $\begin{array}{l}\text { bérelt dolgozók } \\
\text { (fó) }\end{array}$ \\
\hline 2010 & 178 & 20 \\
\hline 2011 & 184 & 20 \\
\hline 2013 & 191 & 30 \\
\hline 2014 & 189 & 30 \\
\hline 2015 & 192 & 70 \\
\hline & 204 & 90 \\
\hline
\end{tabular}

1. táblázat: AutóflexKnott Kft. dolgozóinak létszáma

(Forrás: saját szerkesztés, vállalati adatok alapján)

A piacon levő szakember- és általános munkaerőhiány vállalatunknál is komoly problémát okoz, még a bérmunkaerőként alkalmazott dolgozók mellett is. Ezért a vezetőség úgy döntött, hogy a szakemberhiány megoldására robotokat is vásárol. Fontos szempont volt az is, hogy a robotok 
biztosítsák a megfelelő termelékenységet, a mindig egyenletes és jó minőségű terméket, deazért a meghatározó ok mégis a hiányzó szakember és munkaerő pótlása volt.

Hiszen a Toyota módszer sem igényli a legújabb termelési sorokat, az újabb berendezéseket, a titok a folyamatok, a termelés, termék területén alkalmazott folyamatos fejlesztésben rejlik, valamint a rendszeres beszállítói kapcsolatokban. Van azonban egy nagyon fontos sarkalatos pontja a Toyota folyamat tanulási rendszerének. Jobban járunk, ha először manuális eljárásokat alkalmazunk, ekkor ugyanis megláthatjuk a hibákat, hiszen az ember a legrugalmasabb erőforrás. Amikor a folyamat, az eljárás már tökéletesítve van, akkor szabad csak automatizálni. Sajnos, a megnövekedett vevői igények, a rövid rendelési határidők és a munkaerőhiány miatt ezt nem lehet mindig betartani. Ezért kellett eleinte azzal szembesülnünk, hogy a robotok nagyobb selejt aránnyal termeltek, mint amikor emberi munkaerőt alkalmaztunk. Nem a robotok hibáztak, hanem sok esetben az adott robottal kiváltott folyamatot megelőző műveletből adódtak, amit a robot nem tudott „korrigálni”. Ezért a folyamatainkba olyan megfigyelő rendszert kellett és kell kiépíteni, ami hiba esetén egyből jelzést ad, és nem engedi, hogy a hibás terméket tovább gyártsuk, és nem megfelelő minőségű termék jusson a vevőhöz.

Amit pedig majd még fontosnak látok vállalatunknál bevezetni, az a Toyota elv 14. pontja, amely szerint, amikor már stabilan működnek a folyamataink, a Kaizen és egyéb módszerekkel még tovább finomítsunk és őrizzük meg a kultúránkat. [7,8]

\section{A különböző szervezeti kultúrák közötti azonosságok és különbségek}

A német és a japán szervezeti kultúráknál is fontos szerepet töltenek be a jól megtervezett folyamatok, hisz a legjobb minőséget csak így lehet biztosítani. A japánoknál fogalmazódott meg először, a teljes körű minőségmenedzsment. Először csak a termékek minőségére koncentráltak, da hamar belátták, hogy azt az egész folyamatra ki kell terjeszteni.

A magyar kultúrára is elmondható, hogy folyamataikat megtervezik, de csak rövidtávra, ellentétben a japán, vagy a német vállalatokkal. Pedig nagyon fontos, hogy a vezetési döntéseinket hosszú távú filozófiára építsük. Robert B. McCurry- a Toyota Motors Sales korábbi alelnöke - ezzel kapcsolatosan az alábbiakat fogalmazta meg: „A siker legfontosabb feltétele a türelem, a rövid távú eredmények helyett a hosszú távúak előtérbe helyezése, az emberekbe, a termékekbe és a berendezésekbe való befektetés és a minőség iránti hajthatatlan elkötelezettség"[9]. Sokszor, ha a magyar vállalatnak pénzügyi problémái adódnak, nem azt keresi, hogyan tudná megoldani, hanem inkább feladja, megszünteti a vállalatát, vagy akár készakarva csődbe is viszi. A kis és közép vállatok megelégednek a hazai piacon való szerepléssel és nem szeretnének a külföldi piacok részesei lenni, sőt sok esetben a nagyobb vállalathoz való csatlakozás lehetőségét is elkerülik.

Az Autóflex nem tartozik a magyar hagyományos kis és középvállalatokhoz. Saját magánál sokkal nagyobb külföldi-, német vállalathoz csatlakozott, a Knott-hoz. A Knott Európa egyik legnagyobb nagy múlttal rendelkező vállalata. A közös kapcsolatnak köszönhetően, nem csak Európa számos országában terjeszkedik, hanem Amerikában is forgalmazza az utánfutókat és az alkatrészeit. 
A szervezeti kultúrákban a vezetők meghatározó szerepet töltenek be. A vezetők és a dolgozók között a hierarchia lehet nagy is, mint például a japán kultúrában, de vannak olyan országok is, ahol ez nem nyilvánul meg ilyen élesen. Ezt a vállalatok nagysága is befolyásolja. A német szervezeteknél a vezetők kijelölik a dolgozók számára a feladatokat, és amikor a technológiában meghibásodás, vagy beavatkozás szükséges akkor szakértőként vesznek részt a probléma megoldásában.

Vállalatunknál is meghatározó szerepet töltenek be a vezetők, de a dolgozókkal együttműködve oldják meg a feladatokat, nincs nagy hierarchikus távolság a vezető és dolgozó között. A Knott az Autóflex életében kezdetben a vezető és egyben tanítói szerepet is betöltött. Iránymutatásával tudtuk megvalósítani azt a minőséget, amit egy európai piac elvár a szereplőitől.

A japán szervezetben nem csak a vezetők, mérnökök feladata a felmerülő problémák megoldása, hanem a dolgozók is részt vesznek a folyamatok tökéletesítésében, a veszteségek megszüntetésében. Folyamatos ötletekkel támogatják a termelést. Vállalatunknál ezért is kezdjük kialakítani ezt az ötletrendszert, hisz a dolgozók ismerik a legjobban a folyamatokat, ők látják, hol lehetne kényelmesebbé, logikusabbá tenni. A magyar vállalatoknál egyre több helyen találkozhatunk a japán kultúra jegyeivel. A Lean, vagy Kaizen módszereket egyre nagyobb előszeretettel alkalmazzák, látják az előnyeit, és ezt sokszor magukra is szabják a vállalatok. Ettől lesz övék, a sajátjuk, ezzel egy egyedi csak az ők szervezeti kultúrájukra jellemző vonást alakítanak ki.

A magyar kultúrára a maskulin jegyek a jellemzőek, de vállalatunknál a gondoskodás és törődés is helyet kap.

A japán vállalatok családi vállalkozások, és a dolgozók is úgy érzik, hogy önmaguk a család részei. A vállalatuk iránti lojalitás maximális, a csapatért az egyéni érdeküket is háttérbe szorítják. Ez a magyar szervezetekre nem mondható el, sőt a nagy vállaltok, multik számára ez érthetetlen is, hogy a magyarok szabadidejükben, miért nem viselik a vállalatuk logóját, pólóját. Nem feltétlenül az jelenti, hogy nem elkötelezettek a dolgozók a vállalat iránt, hanem mi máshogy nyilvánítjuk ki a lojalitásunkat.

Az Autóflex munkatársai között nagyon sok olyan dolgozó van, akik a kezdetek óta a vállalatnál dolgoznak. Ők lettek a különböző üzemrészek vezetői, a kiscsapat szinte minden tagja egy újabb csapatot alakított ki. Ez a csapatszellem nem csak a vállalaton belül, hanem a leányvállalatok között is megtalálható. Közösen próbálnak megfelelni a piaci a kihívásoknak, és természetesen azért a versenyszellem is meg van, de melyik családban nincs?! Még a természet is igyekszik egyensúlyra törekedni, de ott is vannak kilengések. Hiszen az egyensúlytól való eltérések olyan változásokat eredményeznek, amelyek előre viszik a vállalatokat, és ami mellett azért megmarad az egészséges verseny is.

\section{Következtetés}

Azt vizsgáltam, hogy Magyarországon működő, részben német tulajdonban levő vállalat termelésébe, hogyan lehet beilleszteni a japán kultúrát.

Megállapítom, hogy a magyar- német-japán kultúra összefonódásával egy egyedi, nem tipikus magyar szervezeti kultúrát sikerült meghonosítani. 
A magyar kis és középvállalatokkal ellentétben az AutóflexKnott Kft. hosszú távra tervez, és egy nagy múlttal rendelkező Knott csoport tagja lett, akik a világ számos országában jelen van termékeivel. A Knott anyavállalat, a német kultúrára jellemzően „szakértőként” támogatták, támogatják az Autóflexet.

A cégcsoport több leányvállalattal is rendelkezik, hogy rugalmasan, költséghatékonyan és a legjobb minőségben tudja kiszolgálni a vevőit. A japán kultúrára jellemző csoportokat, családokat a vállalaton belül is és a csoportok között is megtalálhatjuk. A Toyota-módszer további alkalmazásával még jobbá lehet tenni ezt a sajátos jellegű szervezeti kultúrát, ahol az ember iránti tisztelet megmaradt a nagyvállalattá növekedés ellenére is. A kiemelkedő teljesítmény nem a különálló elemekben keresendőek, hanem az egész rendszerben, amit nap, mint nap gyakorolni kell.

\section{Hivatkozások}

[1] Gy. Bakacsi (1996), Szervezeti magatartás és vezetés, Közgazdasági és Jogi könyvkiadó, Budapest, p. 226.

[2] A. Tóth (2004), A szervezeti (vállalati) kultúra kialakításának elméleti alapjai és modellstruktúrája, in: Gyakorlati controlling kézikönyv, RAABE Tanácsadó és Kiadó Kft., Budapest, 6/3. 20. fejezet, 8

[3] A. E. Matkó (2013), A szervezeti kultúra és a vezetési tulajdonságok szerepe a regionális versenyképességben az észak-alföldi régió önkormányzatainál, Debrecen

[4] Gy. Bakacsi (2010), A szervezeti magatartás alapjai, Alapszakos jegyzet a Budapesti Corvinus Egyetem hallgatói számára, Aula

[5] energetika.13s.hu/pub/msc/epuletgepesz\%20msc/Vez\%E9pszicholF3gia/3/szervkultura .pdf, Megtekintve: 2016.03.08

[6] M. Rother, J. Shock (2012), Tanulj meg látni, LEI Magyarországi Egyesülete

[7] J. K. Liker (2008), A Toyota-módszer- 14 vállalatirányítási alapelv, HVG kiadó Zrt., Budapest

[8] P. Marksbery (2013), The Modern Theory of the Toyota Produktion System, Taylor\&Francis Group.,LLC

[9] J. K. Liker (2008), A Toyota-módszer- 14 vállalatirányítási alapelv, HVG kiadóZrt., Budapest, p. 99.

[10] www.jgypk.u.szeged.hu/tamop13e/tananyag html/sportkultura/kep010.gif 